\title{
Examining the relationship between English language learners' online self-regulation and their self-efficacy
}

\author{
You Su \\ Beijing University of Posts and Telecommunications; Beijing Normal University \\ Chunping Zheng \\ Beijing University of Posts and Telecommunications, Beijing \\ Jyh-Chong Liang, Chin-Chung Tsai \\ National Taiwan Normal University, Taipei
}

This quantitative study investigated the relationship between learners' online self-regulation and their self-efficacy in the context of learning English as a foreign language (EFL). We collected data from two surveys, the online self-regulated English learning (OSEL) and the English language self-efficacy (ELSE), among 424 university students in China. Principal component analyses showed that the OSEL included six sub-scales, namely, goal setting, environment structuring, task strategies, time management, help seeking and self-evaluation, while the ELSE consisted of four factors targeting self-efficacy in listening, speaking, reading, and writing. The correlation analysis confirmed the associations between all scales of the OSEL and those of the ELSE. Furthermore, regression analysis revealed that self-evaluation was the most powerful predictor for explaining participants' variance of self-efficacy in English listening, speaking, and reading. Moreover, learners' environment structuring could significantly explain their self-efficacy in both speaking and writing, whereas goal setting could only predict students' self-efficacy in writing. These findings reveal the intricate relationship between online self-regulation and self-efficacy among the EFL learners, and further highlights the positive role of learners' self-evaluation, environment structuring and goal setting for explaining their English language self-efficacy. Pedagogical implications and future research are discussed at the end of this paper.

\section{Introduction}

Learners' self-regulation has been recognised as a significant variable for understanding the individual differences of second language learners (e.g., Dörnyei \& Ryan, 2015). Studies of second language acquisition (SLA) have shown a growing research interest in the dynamics of self-regulation. Learners' self-regulatory capacity is also a critical factor for the success of language learning (Ching, 2002; Dörnyei, 2005; Dörnyei \& Ryan, 2015; Tseng, Dörnyei, \& Schmitt, 2006). Since learners' self-regulation is usually associated with their self-efficacy, researchers are also calling for more research linking these two constructs of learner characteristics in SLA (Ghonsooly \& Ghanizadeh, 2013; Wang, Schwab, Fenn, \& Chang, 2013; Yusuf, 2011). Several studies have explored the interplay between self-regulation and self-efficacy in the context of learning English as a foreign language (EFL). However, most of these studies were carried out in traditional classroom-based learning environments (e.g., Hamedani, 2013; Kim, Wang, Ahn, \& Bong, 2015; Li \& Wang, 2010). Few empirical investigations have been conducted concerning the relationship between language learners' self-regulation and their self-efficacy in online settings. For this reason, this paper aims to examine the under-researched correlations between students' online self-regulation and their English language selfefficacy among EFL learners in mainland China. 


\section{Literature review}

\section{Self-regulation and online self-regulated learning}

In the academic domain of educational psychology, self-regulation is conceptualised as a process in which learners employ various strategies to regulate and control their own learning (Zimmerman, 2008; Zimmerman \& Kitsantas, 2014). It is understood as a dynamic and multi-dimensional construct involving cognitive, metacognitive, motivational, behavioural, and environmental components (Dörnyei, 2005; Zimmerman, 2008). Self-regulated learning has been approached from diverse theoretical perspectives (see Dörnyei \& Ryan, 2015), and it has been investigated in relation to other variables such as learner beliefs (Bown, 2006; Zheng, Liang, Yang, \& Tsai, 2016), English language proficiency (Bai, Hu, \& Gu, 2014), motivation (Noels, Pelletier, Clément, \& Vallerand, 2000; Ushioda, 2006), and learner autonomy (Kormos \& Csizér, 2014). The emerging empirical evidence consistently indicates that self-regulation is a significant impetus for learners' academic performance (Ching, 2002; Hilden \& Pressley, 2007; Zimmerman \& Schunk, 2011).

As a context-specific construct, students' self-regulatory processes in online learning environments may differ from those in conventional classroom-based settings (Barnard, Lan, To, Paton, \& Lai, 2009; Zheng et al., 2016). Barnard and her colleagues (2009) explored the construct factors of learners' online self-regulation and further classified it into six types: goal setting, time management, environment structuring, help seeking, task strategies, and self-evaluation. Researchers found that learners' online self-regulation is closely connected with their academic success in computer-based learning environments (Winters, Greene, \& Costich, 2008). Research findings also show that online self-regulation is an essential factor guiding students' web-based information searching strategies (Tseng, Liang, \& Tsai, 2014) and helps them organise and integrate information into viable mental models when learning online (Azevedo \& Cromley, 2004). If students fail in online courses due to a lack of self-regulatory learning ability, they may exhibit insufficiency in goal commitment, locus of control, coping strategies, or resilience required to complete tasks (Artino, 2008; Cho \& Shen, 2013).

Although substantial educational research has investigated learners' online self-regulation, little empirical evidence has been reported in the field of SLA (Tsai, Shen, \& Fan, 2013). Since technology-enhanced learning environments provide EFL learners with promising opportunities for improving their language learning both inside and beyond the classrooms (McLoughlin \& Lee, 2010), more studies are needed for better understanding language learners' self-regulatory mechanisms in online settings (Lai \& Gu, 2011; Zheng et al., 2016).

\section{Self-efficacy and English self-efficacy}

Self-efficacy refers to people's beliefs in their abilities to complete specific tasks and attain goals (Bandura, 1997). Studies have revealed the powerful predictive validity of learners' self-efficacy for explaining their academic performance (Pajares, 1996; Schunk, 1995). Research shows that learners having a strong academic self-efficacy are more likely to undertake challenging tasks (Bandura \& Schunk, 1981), whereas students who possess low self-efficacy feel reluctant to deal with challenges and often choose not to engage in difficult tasks (Schunk, 1990).

In recent years, SLA scholars have paid increasing attention to the investigation of EFL learners' English language self-efficacy. For instance, research conducted among university students in Taiwan indicates a close relationship between learners' self-efficacy and performance in writing (Chen \& Lin, 2009). Evidence also shows that self-efficacy plays a mediating role between students' English performance and learning anxiety (Woodrow, 2011). Bandura (1997) suggested that self-efficacy should be surveyed according to specific tasks and contexts since it might vary in different academic domains. Other researchers have also advocated using multidimensional questionnaires instead of general self-efficacy items to assess language learners' self-efficacy (Pajares, 1996; Wang et al., 2013). More recently, Wang, Kim, Bai, and Hu (2014) defined English self-efficacy as ‘one’s belief about how well he/she can successful perform a task in English 
based on his/her past experience' (p. 25). Furthermore, they developed a questionnaire of English selfefficacy for measuring EFL students' self-efficacy in listening, speaking, reading, and writing skills. Their study could be considered as a successful attempt for researching EFL self-efficacy as an individual construct, and the questionnaire can be replicated to evaluate EFL learners' English self-efficacy in other contexts.

\section{Self-regulation, online self-regulation and English self-efficacy}

Understanding how self-regulation is related to self-efficacy is crucial for English language education (Kim et al., 2015). Researchers claim that these two constructs are closely associated in that a high sense of selfregulation enhances learners' beliefs in their academic efficacy (Zimmerman \& Martinez-Pons, 1992). For instance, highly self-efficacious Chinese EFL students reported more frequent employment of self-regulated reading strategies like goal setting, time management, and material selections (Li \& Wang, 2010). Similarly, an investigation at a Korean university revealed that learners with a low self-efficacy profile performed rather differently from those with medium and high self-efficacy profiles in terms of their use of self-regulated learning and language interpretation strategies (Kim et al., 2015). A study in Indonesia also identified close ties between young learners’ strategy use and their self-efficacy beliefs (Anam \& Stracke, 2016).

Thanks to the advancement of information technology, second language learners are empowered with more innovative online applications or practices (Bodnar, Cucchiarini, Strik, \& Hout, 2016). Technology-enhanced language learning practices can not only engage EFL students in self-regulated learning (Lai \& Gu, 2011; Kondo et al., 2012), but also produce a positive impact on their self-efficacy (Henderson, Huang, Grant, \& Henderson, 2012; Kissau, 2012; Wu \& Yang, 2016). In web-based learning settings, students who can employ self-regulatory strategies became more challengeable and more confident in understanding course materials or participating in learning activities (Chang, 2005). Although both self-regulation and self-efficacy are crucial forces affecting learning (Anam \& Stracke, 2016; Barnard et al., 2009; Yukselturk \& Bulut, 2007), the interplay between these two constructs has not been fully explored in online learning settings. Thus, by surveying a sample of Chinese EFL learners with sufficient exposure to an online learning environment, the current research aimed to address the following two questions:

(1) What is the relationship between EFL learners' online self-regulation and their self-efficacy?

(2) What predictive role does EFL learners' online self-regulation play on their self-efficacy?

\section{Method}

\section{Research context}

This investigation took place in the context of a mandatory EFL language course at a university in Beijing, China. A blended learning mode was adopted in the course with the aim of developing students' overall language competence. During the 16-week course, instructors and students were required to meet once every other week, when a 100-minute in-class instruction was conducted. After class, students were required to make full use of the online language learning materials, and to complete a variety of self-regulated language learning tasks through two well-established online English language learning systems. One system is the new perspective foreign language teaching and learning platform (Long, 2012), and the other is the online teaching and formative assessment system (Zheng, Lu, \& Wang, 2015). The two systems are effective in assisting Chinese EFL learners' online English learning, and are well accepted by Chinese students in terms of their usefulness and ease of use (see Long, 2012; Zheng, Su, \& Lian, 2014).

\section{Participants}

This research involved a convenience sample of 424 first-year undergraduate students (around 18-19 years old) enrolled at the university. Most of the participants were majoring in computer science, telecommunications, and electronic information science. Thus, male students (271 males) outnumbered female students in the current study. All the participants had completed formal English language learning in 
junior and senior high schools (6 years in total) before entering the university. They also had 16-week prior experience in taking the blended English language course at the university. Descriptive data showed that over half (69.1\%) of the participants spent around 3 hours per week for learning English online after class.

\section{Instruments}

Two questionnaires were used to investigate EFL learners' online self-regulation and English language selfefficacy. The two questionnaires were designed based on adaption of two previous instruments with adequate reliability and validity. A detailed description of the two instruments is presented below.

Questionnaire evaluating EFL students' online self-regulation

This research adapted the online self-regulated English learning (OSEL) questionnaire (Zheng et al., 2016) to assess English language learners' online self-regulation. With reference to the theories of self-regulation in educational psychology (Barnard et al., 2009; Zimmerman \& Schunk, 2011), the instrument was developed to measure EFL learners' abilities to self-regulate and monitor their learning in online settings. The original OSEL was reported to have high internal consistency reliability with an overall Cronbach's alpha value of 0.91 (Zheng et al., 2016). Based on our previous interview with participants, we made some modifications of the original instrument by adding a few new items, such as 'I make use of my fragmental time to learn English online.' and 'Although we don't have to attend daily online English classes, I still try to distribute my studying time evenly across days.' in the dimension of time management. The final instrument for the English language learners' online self-regulation in this study consisted of 30 items. Being similar to Barnard et al.'s (2009) taxonomy, it was further divided into 6 factors: goal setting (5 items), environment structuring (5 items), task strategies (5 items), time management (5 items), help seeking (5 items), and self-evaluation (5 items). As with previous surveys (Barnard et al., 2009; Zheng et al., 2016), we adopted a 5-point Likert scale with values ranging from 1 (do not agree at all) to 5 (strongly agree). The sample questions of the six components are as follows:

(1) Goal setting: I set goals to help me manage study time for my online English learning.

(2) Environment structuring: I know where I can learn English online most efficiently.

(3) Task strategies: I read aloud the English instructional materials posted online to fight against distractions.

(4) Time management: I make use of my fragmental time to learn English online.

(5) Help seeking: I share my problems with my classmates online so we know what we are struggling with and how to solve our problems.

(6) Self-evaluation: I communicate with my teachers to find out how I am doing with my online English learning.

Questionnaire assessing students' English language self-efficacy

The other instrument, the English language self-efficacy (ELSE) questionnaire, was adapted from Wang et al. (2014) to assess students' English self-efficacy in four skills: listening, speaking, reading, and writing. The original questionnaire consisted of 32 items concerning students' beliefs about how capable they are to complete specific tasks in English. The original survey showed that all the sub-scales had acceptable reliability and validity, with alpha coefficient being around $0.88-0.92$ for each dimension. High overall internal consistency reliability ( $\alpha=0.99$ ) was also reported in a subsequent study conducted by Kim et al. (2015). To better serve the purpose of this study, the original instrument was also modified. First of all, some items were revised to better suit the learning context of Chinese college students in this study. For example, we changed the word university in 'Can you describe the way to the university from the place where you live in English?' to university sports stadium, because most of the college students in mainland China live in the school dormitories within the campus. Secondly, 5 additional items, for example, 'Can you do English presentations in class?’ were added to reflect the latest requirements for college English language teaching by the Ministry of Education of China (2007). In addition, following Wang et al.'s (2014) suggestions, 7 new items, for example, 'Can you understand English lectures of general topics?' were included in the instrument to better reflect EFL learners' comprehensive ability to use English. Research shows that a 5-point Likert scale is an acceptable approach to measure self-efficacy (Maurer \& Andrews, 2000; Maurer \& Pierce, 1998), 
and it has been successfully adopted to measure self-efficacy in different research contexts (see Haddad \& Taleb, 2016; Hartmann, 2012). Thus, the ELSE questionnaire was also presented in the format of a 5-point Likert scale with values ranging from 1 (I cannot do it at all) to 5 (I can do it well). The four factors in the ELSE are described below, with one sample item each provided:

(1) Listening efficacy: Can you understand English lectures of general topics?

(2) Speaking efficacy: Can you ask people for help in English?

(3) Reading efficacy: Can you read English newspapers?

(4) Writing efficacy: Can you use accurate grammar when you write English essays?

Using an iterative process of repeated independent translation and back-translation (Brislin, 1970), all the questionnaires items were converted into Chinese since English is not the native language of the participants. For content and construct validity (Carmines \& Zeller, 1979), the established OSEL and ELSE instruments were then evaluated by two external experts with experience in doing quantitative research on English language education. Based on the comments from the experts, items inappropriate to the target population were eliminated, and the wording of the statements was revised for ease of understanding. Following You and Dörnyei's (2016) study, we invited ten university students to examine the items before administering the survey. Items that were ambiguous for the target population were further amended until there was no difficulty for students to respond to the surveys. The English version of the two finalised questionnaires is presented in the Appendix.

\section{Data collection and analysis}

All participants volunteered to answer the OSEL and ELSE questionnaires in one setting. Before responding to the questionnaires, the participants were informed of the anonymous nature of the data collection process. They were also told that their responses would be kept confidential and that they had the right to withdraw at any time. It took 15-20 minutes for all the respondents to complete the survey. After deleting invalid questionnaire data, 424 students' responses remained and were further analysed to answer the research questions.

The present study first employed principal component analysis to examine the component structure of the OSEL and ELSE questionnaires. The reliability coefficient was also collected to ensure the internal consistency of the measurements as a whole. Pearson correlation analysis was then adopted to analyse the relationship between the OSEL and ELSE factors. Finally, stepwise regression analyses between the scales of the two instruments were implemented. Research has examined self-efficacy as an outcome and supported the notion that self-regulated strategies might affect self-efficacy (Bandura \& Schunk, 1981; Miksza, 2015; Schunk, 2003). Thus, the current study regarded the OSEL scales as predictor variables and the ELSE scales as outcome variables.

\section{Results}

\section{Principal component analysis of the OSEL questionnaire}

Table 1 displays the outcome of principal component analysis for the OSEL questionnaire. This study used the principal component analysis with varimax rotation method to clarify the structure of the OSEL questionnaire. As suggested by Stevens (1996), items with loadings weighed greater than 0.40 on the relevant factor and less than 0.40 on the non-relevant factors were kept in the finalised OSEL. Thus, 20 items were retained and grouped into six dimensions, with a total of $72.91 \%$ of variance explained. Results indicate that students showed the strongest agreement on environment structuring (Mean $=4.10, S D=0.72$ ), followed by goal setting (Mean $=3.62, S D=0.77$ ), help seeking (Mean $=3.55, S D=0.83$ ), self-evaluation (Mean $=3.33$ $S D=0.80)$, time management $($ Mean $=3.26, S D=0.82)$, and task strategies $($ Mean $=3.04, S D=0.87)$. The reliability coefficient for each scale ranged from 0.64 to 0.90 , with an overall reliability of 0.93 , making it acceptable in terms of internal consistency of the measurements. 
Table 1

Rotated factor loadings and Cronbach's alpha values for the six sub-scales of the OSEL

\begin{tabular}{|c|c|c|c|c|c|c|}
\hline & Factor 1 & Factor 2 & Factor 3 & Factor 4 & Factor 5 & Factor 6 \\
\hline \multicolumn{7}{|c|}{ Factor 1: Goal setting $(\mathrm{GS}), \alpha=0.90$, Mean $=3.62, S D=0.77$} \\
\hline GS 1 & 0.75 & & & & & \\
\hline GS 2 & 0.77 & & & & & \\
\hline GS 3 & 0.77 & & & & & \\
\hline GS 4 & 0.77 & & & & & \\
\hline GS 5 & 0.67 & & & & & \\
\hline \multicolumn{7}{|c|}{ Factor 2: Environment structuring (ES), $\alpha=0.85$, Mean $=4.10, S D=0.72$} \\
\hline ES 1 & & 0.82 & & & & \\
\hline ES 2 & & 0.85 & & & & \\
\hline ES 3 & & 0.70 & & & & \\
\hline ES 4 & & 0.83 & & & & \\
\hline \multicolumn{7}{|c|}{ Factor 3: Task strategies (TS), $\alpha=0.64$, Mean $=3.04, S D=0.87$} \\
\hline TS 1 & & & 0.61 & & & \\
\hline TS 2 & & & 0.85 & & & \\
\hline \multicolumn{7}{|c|}{ Factor 4: Time management (TM), $\alpha=0.72$, Mean $=3.26, S D=0.82$} \\
\hline TM 1 & & & & 0.70 & & \\
\hline TM 2 & & & & 0.63 & & \\
\hline TM 3 & & & & 0.61 & & \\
\hline \multicolumn{7}{|c|}{ Factor 5: Help seeking (HS), $\alpha=0.82$, Mean $=3.55, S D=0.83$} \\
\hline HS 1 & & & & & 0.79 & \\
\hline HS 2 & & & & & 0.79 & \\
\hline HS 3 & & & & & 0.72 & \\
\hline \multicolumn{7}{|c|}{ Factor 6: Self-evaluation (SE), $\alpha=0.83$, Mean $=3.33, S D=0.80$} \\
\hline SE 1 & & & & & & 0.61 \\
\hline SE 2 & & & & & & 0.66 \\
\hline SE 3 & & & & & & 0.60 \\
\hline
\end{tabular}

Note. Overall reliability coefficient: 0.93 ; total variance explained: $72.91 \%$

\section{Principal component analysis of the ELSE questionnaire}

With regard to the ELSE instrument, we applied a similar process of principal component analysis to identify its structure. Consequently, 28 items of the questionnaire and 4 factors were displayed in the finalised ELSE, and these factors explained $61.32 \%$ of the total variance. As presented in Table 2, participants' responses were grouped into four sub-scales, and the students scored highest on writing (Mean $=3.95, S D=0.54$ ), followed by speaking (Mean $=3.83, S D=0.60$ ), reading (Mean $=3.58, S D=0.62)$, and listening (Mean $=$ $3.19, S D=0.62$ ). The reliability coefficients (Cronbach's alpha) ranged from 0.84 to 0.93 , with an overall alpha of 0.95 , suggesting that the internal consistency was sufficient and the four scales were adequately reliable to assess students’ English language self-efficacy. 
Table 2

Rotated factor loadings and Cronbach's alpha values for the four sub-scales of the ELSE

\begin{tabular}{|c|c|c|c|c|}
\hline & Factor 1 & Factor 2 & Factor 3 & Factor 4 \\
\hline \multicolumn{5}{|c|}{ Factor 1: Listening, $\alpha=0.88$, Mean $=3.19, S D=0.62$} \\
\hline Listening 1 & 0.68 & & & \\
\hline Listening 2 & 0.60 & & & \\
\hline Listening 3 & 0.72 & & & \\
\hline Listening 4 & 0.73 & & & \\
\hline Listening 5 & 0.57 & & & \\
\hline Listening 6 & 0.71 & & & \\
\hline Listening 7 & 0.67 & & & \\
\hline Listening 8 & 0.64 & & & \\
\hline \multicolumn{5}{|c|}{ Factor 2: Speaking, $\alpha=0.93$, Mean $=3.83, S D=0.60$} \\
\hline Speaking 1 & & 0.61 & & \\
\hline Speaking 2 & & 0.68 & & \\
\hline Speaking 3 & & 0.73 & & \\
\hline Speaking 4 & & 0.78 & & \\
\hline Speaking 5 & & 0.74 & & \\
\hline Speaking 6 & & 0.72 & & \\
\hline Speaking 7 & & 0.77 & & \\
\hline Speaking 8 & & 0.68 & & \\
\hline Speaking 9 & & 0.62 & & \\
\hline Speaking 10 & & 0.66 & & \\
\hline \multicolumn{5}{|c|}{ Factor 3: Reading, $\alpha=0.86$, Mean $=3.58, S D=0.62$} \\
\hline Reading 1 & & & 0.78 & \\
\hline Reading 2 & & & 0.76 & \\
\hline Reading 3 & & & 0.78 & \\
\hline Reading 4 & & & 0.70 & \\
\hline \multicolumn{5}{|c|}{ Factor 4: Writing, $\alpha=0.84$, Mean $=3.95, S D=0.54$} \\
\hline Writing 1 & & & & 0.70 \\
\hline Writing 2 & & & & 0.52 \\
\hline Writing 3 & & & & 0.51 \\
\hline Writing 4 & & & & 0.66 \\
\hline Writing 5 & & & & 0.72 \\
\hline Writing 6 & & & & 0.69 \\
\hline
\end{tabular}

Note. Overall reliability coefficient: 0.95 ; total variance explained: $61.32 \%$

\section{Correlation between the factors of OSEL and ELSE}

In order to understand the association between the learners' online self-regulation and their self-efficacy in the process of learning English, Pearson correlation analysis was performed based on participants' responses to the two questionnaires. Table 3 shows the correlation values among all the sub-scales.

Table 3

Correlations between EFL students'online self-regulation and self-efficacy

\begin{tabular}{lllllll}
\hline Factor & GS & ES & TS & TM & HS & SE \\
\hline Listening & $0.22^{* * *}$ & $0.12^{* * *}$ & $0.07^{* * *}$ & $0.19^{* * *}$ & $0.17^{* * *}$ & $0.28^{* * *}$ \\
Speaking & $0.28^{* * *}$ & $0.22^{* * *}$ & $0.15^{* * *}$ & $0.21^{* * *}$ & $0.23^{* * *}$ & $0.32^{* * *}$ \\
Reading & $0.22^{* * *}$ & $0.14^{* * *}$ & $0.10^{* * *}$ & $0.16^{* * *}$ & $0.17^{* * *}$ & $0.24 * * *$ \\
Writing & $0.37 * * *$ & $0.27^{* * *}$ & $0.14^{* * *}$ & $0.24 * * *$ & $0.25^{* * *}$ & $0.31^{* * *}$ \\
\hline
\end{tabular}

Note. ${ }^{* * *} p<.001$

GS: goal setting; ES: environment setting; TS: task strategies; TM: time management; HS: help seeking; SE: self-evaluation 
Statistically significant positive correlations were found between the scales in OSEL and those in ELSE ( $r=$ 0.07-0.37, $p<0.001$ ). However, a close analysis of the correlation coefficient uncovered some interesting results. First, it showed that all the scales of OSEL have relatively closer relations with self-efficacy in speaking $(r=0.15-0.32)$ and writing $(r=0.14-0.37)$ than with self-efficacy in other skills. The students with higher self-regulation also tended to be certain about their ability in listening and reading, but the correlation coefficient values, though significant, were relatively low $(r=0.07-0.28)$. Second, among the six factors of OSEL, self-evaluation ( $r=0.24-0.31)$ and goal setting $(r=0.22-0.37)$ turned out to be more correlated with all the scales in ELSE than the other four factors (i.e., ES, TS, TM, HS). Third, task strategies were least correlated with all the four scales in ELSE ( $r=0.07,0.15,0.10,0.14$ respectively).

\section{Stepwise regression analysis of predicting students' ELSE based on OSEL}

The study then conducted regression analysis to further evaluate the predictive power of the OSEL factors for the students' ELSE. As Table 4 shows, regression analysis revealed that the OSEL factor self-evaluation made significant predictions for all scales in the ELSE survey, except for the factor of writing. To be specific, self-evaluation significantly and positively predicted the listening $(\beta=0.28, t=5.87, p<0.001)$, speaking $(\beta=0.27, t=5.51, p<0.001)$, and reading $(\beta=0.24, t=5.12, p<0.001)$ scales. It indicated that selfevaluation played an important role on most aspects of learners' English language self-efficacy. In other words, the students with higher self-evaluation capacity in the online English learning environment would be more likely to possess higher English language self-efficacy in listening, speaking, and reading.

Interestingly, environment structuring was also found to have positive predictions for learners' efficacy in the two productive English language skills, namely speaking $(\beta=0.13, t=2.56, p<0.05)$ and writing $(\beta=0.12, t$ $=2.25, p<0.05$ ). That is, the students with stronger capacity in environment structuring tended to feel more self-efficacious in English speaking and writing. Besides, the goal-setting factor of the OSEL could only positively predict the learners' English writing self-efficacy $(\beta=0.31, t=6.05, p<0.001)$. This result indicates that the students' goal setting played a role in their self-efficacy in English writing.

In sum, the regression results suggest that the self-evaluation factor of the OSEL plays a powerful role in predicting all the aspects of students' English efficacy except for the writing self-efficacy. It also indicates that environment structuring is the second variable to predict the learners' English self-efficacy related to productive skills, namely speaking and writing. Besides, goal setting acts as a significant predictor for the learners' self-efficacy in English writing.

Table 4

Stepwise regression model for predicting students' English self-efficacy $(n=424)$

\begin{tabular}{lllllll}
\hline Self-efficacy & B & S.E. & $\beta$ & T & R \\
\hline Listening & Self-evaluation & & & & & \\
& Constant & 0.21 & 0.03 & 0.28 & $5.87^{* * *}$ & 0.28 \\
& & 2.45 & 0.12 & & $19.97^{* * *}$ & \\
Speaking & & & & & \\
& Self-evaluation & 0.20 & 0.04 & 0.27 & $5.51^{* * *}$ & 0.34 \\
& Environment structuring & 0.11 & 0.04 & 0.13 & $2.56^{*}$ & \\
& Constant & 2.73 & 0.17 & & $15.95^{* * *}$ & \\
Reading & & & & & \\
& Self-evaluation & 0.19 & 0.04 & 0.24 & $5.12^{* * *}$ & 0.24 \\
& Constant & 2.96 & 0.13 & & $23.55^{* * *}$ & \\
& & & & & & \\
& Griting & 0.22 & 0.04 & 0.31 & $6.05^{* * *}$ & 0.39 \\
& Goal setting & 0.09 & 0.04 & 0.12 & $2.25^{*}$ & \\
& Environment structuring & 2.81 & 0.15 & & $18.92^{* * *}$ & \\
\hline
\end{tabular}

Note. ${ }^{*} p<.05 ;{ }^{* *} p<.01 ;{ }^{* * *} p<.001$ 


\section{Discussion}

This study employed two questionnaires to explore the relationship between EFL learners' online selfregulation and their English language self-efficacy. Our findings reveal that both instruments are valid and reliable for assessing students' online self-regulation and their English language self-efficacy. Firstly, there were six factors in learners' self-regulation online: goal setting, environment structuring, task strategies, time management, help seeking, and self-evaluation. The questionnaire assessing online self-regulation displayed the same structure of factors as Barnard et al.'s (2009) research. Furthermore, learners showed self-efficacy in listening, speaking, reading, and writing, further elaborating the internal structure of English language selfefficacy proposed by Wang and his colleagues (2014). Finally, correlation and stepwise regression analyses disclosed the intricate relationship between the two theoretical constructs.

\section{Correlations between EFL learners' online self-regulation and their self-efficacy}

Results through correlation analysis indicate that there are reciprocal relationships between EFL students' online self-regulation and their English self-efficacy. This finding provides support for the potential bidirectional nature of the relationships between self-regulation and self-efficacy (e.g., Boekaerts, Pintrich, \& Zeider, 2005). Learners with higher self-efficacy may be more self-regulated in learning. Likewise, learners who demonstrate better self-regulatory capacity tend to be more self-efficacious. This result is also in accordance with previous findings about the positive link between self-regulated language learning strategy and self-efficacy identified in traditional classroom-based learning settings (e.g., Bai et al., 2014; Kim et al., 2015; Magogwe \& Oliver, 2007; Yusuf, 2011). Moreover, it enabled us to see their close relationship in online learning environments. The more sophisticated learners were in monitoring their online learning process, the more confident they were in their productive skills of speaking and writing. In addition, compared with other factors in online self-regulation, learners' self-evaluation and goal setting in online learning had relatively higher correlation to their English language self-efficacy. This finding echoes the argument that the practice of self-evaluation and goal setting are influential arbitrators of human agency that could alter thinking and subsequent behaviours (Bandura, 1997).

\section{Predictive roles of EFL students' online self-regulation on their self-efficacy}

The first finding of regression analysis reveals that self-evaluation is a significant predictor for most factors of students' English self-efficacy, namely, listening, speaking, and reading. Self-evaluation usually involves learners' regular assessment and monitoring of their learning progress and is regarded as a critical factor for enhancing their self-efficacy (Bandura, 1986; Boekaerts et al., 2005). Our study further verified this view in the context of online EFL learning. Self-evaluation serves as a metacognitive means for foreign language learners to self-diagnose their strengths and weaknesses (Dolosic, Brantmeier, Strube, \& Hogrebe, 2016). Through effective self-evaluation, EFL learners can become more aware of their learning goals and expectations. Besides, Léger (2009) found that learners' perceived confidence in second language speaking increased after a 12-week practice of self-evaluation, thus highlighting the potential cognitive and affective benefits of self-evaluation. Similar evidence can also be found in Butler and Lee's (2010) study with respect to the positive influence of self-evaluation on students' confidence in learning English.

Although this study indicates the significance of self-evaluation for predicting self-efficacy, research has reported that students are seldom put in charge of assessing their own learning (Luoma \& Tarnanen, 2003; Schunk, 2003). It is especially true for East Asian EFL students, who show strong dependency on teachers and usually shy away from direct engagement in the evaluation process (see Chan, Spratt, \& Humphreys, 2002; Chen, 2008; Littlewood, 1999). Dörnyei and Tseng (2009) pointed out that a potential trouble spot in SLA is 'the learners' inadequacy in making realistic and sufficiently specific appraisal of their progress, which prevents them from activating relevant and effective action control strategies that could amend or compensate for shortcomings' (p. 131). The present study further suggests that instructors should pay special attention to learners' self-evaluation in the online learning setting in order to promote their English selfefficacy. 
This study also found that environment structuring is a major predictor for English language self-efficacy in both speaking and writing. It suggests that EFL learners with more environment structuring strategies during a web-based learning process tend to be more self-efficacious in speaking and writing. This is in accordance with the view of social cognitive researchers who regard the social and physical environment as 'a resource for self-enhancing forethought, volitional control, and self-reflection' (Boekaerts et al., 2005, p. 25). Environment structuring in this study mainly concerns finding a proper environment that helps learners concentrate on learning and enhance their efficiency when learning online. Research has shown that, in a supportive learning environment, language learners' self-confidence and motivation to interact grows (Ushioda, 2003), and they are less likely to give up learning (Noels et al., 2000). Besides, knowing how to concentrate and block out outside distractions is important for effective learning (Corno, 1993; Weinstein, Schulte, \& Palmer, 1987). As indicated in this study, environmental self-regulation techniques are of particular significance for learners' speaking and writing self-efficacy. In order to achieve more effective online learning, learners usually need to use these strategies to restructure their learning settings for high concentration (Boekaerts et al., 2005; Zimmerman \& Risemberg, 1997).

Additionally, it is worth noting that the EFL students' goal setting during their online learning is another significant variable for explaining their writing self-efficacy. Writing has long been recognised as a characteristically goal-oriented activity (Bereiter \& Scardamalia, 1987; Cumming, 2006). Goal setting about the use of language, rhetoric, and ideas serves as a viable, effective focus to guide students' English writing (Cumming, 2006; Cumming, Busch, \& Zhou, 2002). Through the guidance of writing goals, intentional learning will happen and students will obtain satisfaction and achievement (Cumming, 1986), which may further promote their writing self-efficacy. The goal-setting process also helps learners develop and exercise metacognitive skills in the process of managing their writing tasks. The present blended course offered learners diverse forms of learning materials online. Learners usually needed to plan their language learning goals and learning strategies continuously so that they could have better performance during the process of online learning (Lee \& Tsai, 2011). With clear learning goals, learners would also feel more self-efficacious about their English writing online.

\section{Implications}

This study provides insights into the relationship between students' online self-regulation and self-efficacy in an EFL learning context. Results reveal different layers of correlation between the scales of the two constructs. According to the results, self-evaluation is identified as the most influential factor explaining students' sense of self-efficacy in English listening, speaking, and reading. Moreover, environment structuring is also a significant predictor for perceived English self-efficacy in speaking and writing, whereas goal setting can only predict students' English self-efficacy in writing.

These findings could provide important implications for fostering learners' English language self-efficacy. First and foremost, online self-evaluation plays the most powerful predicative role in learners' English language self-efficacy. Therefore, developers of online language learning systems need to employ technological innovations that provide access for students to receive constant and timely evaluative feedback on their learning process. Instructors are encouraged to stimulate learners' self-evaluation in the process of developing learning materials. Second, students with strong self-regulatory ability in environment structuring tend to possess higher confidence in speaking and writing self-efficacy. This serves as a reminder for English teachers of the necessity of training learners to acquire adequate environmental self-regulatory skills for online learning. Third, students' writing self-efficacy can be predicted by their goal setting in online learning environments. Hence, English language instructors should help students develop their self-efficacy through setting specific goals for their own online learning.

\section{Limitations and future studies}

Several limitations of this study should be noted. Although this study provides evidence concerning the relationship between online self-regulation and self-efficacy, the fact that the respondents were from only one university limits the generalisability of our findings. Our participants all resided in mainland China, and it is 
possible that the findings might be affected by the Chinese sociocultural context. In addition, principal component and stepwise regression analyses may be limited in revealing the potential structural relationships between the two research constructs. Moreover, self-report survey results are still insufficient for probing deeply into the dynamics of self-regulation and English self-efficacy.

Drawing upon the above-mentioned limitations, we propose several initiatives for future studies. Researchers may still need to use random sampling to ensure adequate representation based on either student profiles or university profiles and further improve the validation of the research findings. Other data analysis methods, such as confirmatory factor analysis and structural equation modelling, are also recommended for providing more insights about self-regulation and self-efficacy. Moreover, in-depth qualitative studies through interviews and observations may help educators gain a fuller understanding of EFL learners' online selfregulation and their self-efficacy. Finally, research in other educational settings or cultural contexts could shed more light on the complex interplay between language learners' online self-regulation and their selfefficacy.

\section{Acknowledgements}

This research was supported by the Humanities and Social Sciences Fund of Chinese Ministry of Education (Grant 16YJC740099) and the teaching reform projects of Beijing University of Posts and Telecommunications (Grant 2016JY50 and 2017JY64).

\section{References}

Anam, S., \& Stracke, E. (2016). Language learning strategies of Indonesian primary school students: In relation to self-efficacy beliefs. System, 60, 1-10. http://dx.doi.org/10.1016/j.system.2016.05.001

Artino, A. R. (2008). Motivational beliefs and perceptions of instructional quality: Predicting satisfaction with online training. Journal of Computer Assisted Learning, 24(3), 260-270. http://dx.doi.org/10.1111/j.1365-2729.2007.00258.x

Azevedo, R., \& Cromley, J. G. (2004). Does training on self-regulated learning facilitate students’ learning with hypermedia? Journal of Educational Psychology, 96(3), 523-535. http://dx.doi.org/10.1037/0022-0663.96.3.523

Bai, R., Hu, G., \& Gu, P. Y. (2014). The relationship between use of writing strategies and English proficiency in Singapore primary schools. The Asia-Pacific Education Researcher, 23(3), 355-365. http://dx.doi.org/10.1007/s40299-013-0110-0

Bandura, A. (1986). Social foundations of thought and action: A social cognitive theory. Englewood Cliffs, NJ: Prentice Hall.

Bandura, A. (1997). Self-efficacy: The exercise of control. New York, NY: Freeman.

Bandura, A., \& Schunk, D.H. (1981). Cultivating competence, self-efficacy, and intrinsic interest through proximal self-motivation. Journal of Personality and Social Psychology, 41(3), 586-598. http://dx.doi.org/10.1037/0022-3514.41.3.586

Barnard, L., Lan, W. Y., To, Y. M., Paton, V. O., \& Lai, S. L. (2009). Measuring self-regulation in online and blended learning environments. Internet \& Higher Education, 12(1), 1-6.

http://dx.doi.org/10.1016/j.iheduc.2008.10.005

Bereiter, C., \& Scardamalia, M. (1987). The psychology of written composition. Hillsdale, NJ: Erlbaum.

Bodnar, S., Cucchiarini, C., Strik, H., \& Hout, R. V. (2016). Evaluating the motivational impact of CALL systems: Current practices and future directions. Computer Assisted Language Learning, 29(1), 1-27. http://dx.doi.org/10.1080/09588221.2014.927365

Boekaerts, M., Pintrich, P. R., \& Zeider, M. (2005). Handbook of self-regulation. San Diego, CA: Academic Press.

Bown, J. (2006). Locus of learning and affective strategy use: Two factors affecting success in self-instructed language learning. Foreign Language Annals, 39(4), 640-659. http://dx.doi.org/10.1111/j.1944-9720.2006.tb02281.x 
Brislin, R. W. (1970). Back-translation for cross-cultural research. Journal of Cross-Cultural Psychology, 1(3), 185-216. http://dx.doi.org/10.1177/135910457000100301

Butler, Y. G., \& Lee, J. (2010). The effects of self-assessment among young learners of English. Language Testing, 27(1), 5-31. http://dx.doi.org/10.1177/0265532209346370

Carmines, E. G., \& Zeller, R. A. (1979). Reliability and validity assessment. Newbury Park, CA: Sage.

Chan, V., Spratt, M., \& Humphreys, G. (2002). Autonomous language learning: Hong Kong tertiary students' attitude and behaviors. Evaluation and Research in Education, 16(1), 1-18. http://dx.doi.org/10.1080/09500790208667003

Chang, M. M. (2005). Applying self-regulated learning strategies in a web-based instruction-an investigation of motivation perception. Computer Assisted Language Learning, 18(3), 217-230. http://dx.doi.org/10.1080/09588220500178939

Chen, M. C., \& Lin, H. J. (2009). Self-efficacy, foreign language anxiety as predictors of academic performance among professional program students in a general English proficiency writing test. Perceptual \& Motor Skills, 109 (2), 420-430. http://dx.doi.org/10.2466/PMS.109.2.420-430

Chen, Y. M. (2008). Learning to self-assess oral performance in English: A longitudinal case study. Language Teaching Research, 12(2), 235-262. http://dx.doi.org/10.1177/1362168807086293

Ching, L. C. (2002). Strategy and self-regulation instruction as contributors to improving students' cognitive model in an ESL program. English for Specific Purposes, 21(3), 261-289. http://dx.doi.org/10.1016/S0889-4906(01)00008-4

Cho, M. H., \& Shen, D. (2013). Self-regulation in online learning. Distance Education, 34(3), 290-301. http://dx.doi.org/10.1080/01587919.2013.835770

Corno, L. (1993). The best-laid plans: Modern conceptions of volition and educational research. Educational Researcher, 22(2), 14-22. Retrieved from http://www.jstor.org/stable/1176169

Cumming, A. (1986). Intentional learning as a principle for ESL writing instruction: A case study. TESL Canada Journal, 3(special issue), 69-83. http://dx.doi.org/10.18806/tesl.v3i0.995

Cumming, A. (2006). Introduction, purpose, and conceptual foundations. In A. Cumming (Ed.), Goals for academic writing: ESL students and their instructors (pp. 1-17). Amsterdam: John Benjamins.

Cumming, A., Busch, M., \& Zhou, A. (2002). Investigating learners' goals in the context of adult secondlanguage writing. In S. Ransdell \& M. Barbier (Eds.), New directions for research in L2 (pp. 189-208). Dordrecht: Kluwer.

Dolosic, H. N., Brantmeier, C., Strube, M., \& Hogrebe, M. C. (2016). Living language: Self-assessment, oral production, and domestic immersion. Foreign Language Annals, 49(2), 1-15. http://dx.doi.org/10.1111/flan.12191

Dörnyei, Z. (2005). The psychology of the language learner: Individual differences in L2 acquisition. Mahwah, NJ: Lawrence Erlbaum Associates.

Dörnyei, Z., \& Ryan, S. (2015). The psychology of the language learner revisited. New York, NY: Routledge.

Dörnyei, Z., \& Tseng, W. T. (2009). Motivational processing in interactional tasks. In A. Macky \& C. Polio (Eds.), Multiple perspectives on interaction: Second language research in honor of Susan M. Gass (pp. 117-134). London: Routledge.

Ghonsooly, B., \& Ghanizadeh, A. (2013). Self-efficacy and self-regulation and their relationship: A study of Iranian EFL teachers. The Language Learning Journal, 41(1), 68-84. http://dx.doi.org/10.1080/09571736.2011.625096

Haddad, S. I., \& Taleb, R. A. (2016). The impact of self-efficacy on performance (an empirical study on business faculty members in Jordanian universities). Computers in Human Behavior, 55, 877-887. http://dx.doi.org/10.1016/j.chb.2015.10.032

Hamedani, S. H. H. (2013). The relationship between self-efficacy and self-regulation in vocabulary acquisition of Iranian EFL learners. Journal of Academic and Applied Studies, 3(1), 20-31. Retrieved from https://pdfs.semanticscholar.org/cae0/5fe49ea93e5b510548f8c1fdefa9fd649e57.pdf

Hartmann, E. (2012). A scale to measure teachers' self-efficacy in deaf-blindness education. Journal of Visual Impairment \& Blindness, 106(11), 728-738. Retrieved from ERIC database. (EJ996228)

Henderson, M., Huang, H., Grant, S., \& Henderson, L. (2012). The impact of Chinese language lessons in a virtual world on university students' self-efficacy beliefs. Australasian Journal of Educational Technology, 28(3), 400-419. http://dx.doi.org/10.14742/ajet.842 
Hilden, K. R., \& Pressley, M. (2007). Self-regulation through transactional strategies instruction. Reading and Writing Quarterly, 23(1), 51-75. http://dx.doi.org/10.1080/10573560600837651

Kim, D. H., Wang, C., Ahn, H. S., \& Bong, M. (2015). English language learners' self-efficacy profiles and relationship with self-regulated learning strategies. Learning \& Individual Differences, 38, 136-142. http://dx.doi.org/10.1016/j.lindif.2015.01.016

Kissau, S. (2012). Perceptions of self-efficacy for two types of second language methods instruction. Computer Assisted Language Learning, 25(4), 1-23. http://dx.doi.org/10.1080/09588221.2011.587436

Kondo, M., Ishikawa, Y., Smith, C., Sakamoto, K., Shimomura, H., \& Wada, N. (2012). Mobile assisted language learning in university EFL courses in Japan: Developing attitudes and skills for self-regulated learning. ReCALL, 24(2), 169-187. http://dx.doi.org/10.1017/s0958344012000055

Kormos, J., \& Csizér, K. (2014). The interaction of motivation, self-regulatory strategies, and autonomous learning behavior in different learner groups. TESOL Quarterly, 48(2), 275-299. http://dx.doi.org/10.1002/tesq.129

Lai, C., \& Gu, M. (2011). Self-regulated out-of-class language learning with technology. Computer Assisted Language Learning, 24(4), 317-335. http://dx.doi.org/10.1080/09588221.2011.568417

Lee, S. W.-Y., \& Tsai, C.-C. (2011). Students' perceptions of collaboration, self-regulated learning, and information seeking in the context of internet-based learning and traditional learning. Computers in Human Behavior, 27(2), 905-914. http://dx.doi.org/10.1016/j.chb.2010.11.016

Léger, D. D. S. (2009). Self-assessment of speaking skills and participation in a foreign language class. Foreign Language Annals, 42(1), 158-178. http://dx.doi.org/10.1111/j.1944-9720.2009.01013.x

Li, Y., \& Wang, C. (2010). An empirical study of reading self-efficacy and the use of reading strategies in the Chinese EFL context. Asian EFL Journal, 12(2), 144-162. Retrieved from https://www.asian-efljournal.com/771/quarterly-journal/2010/06

Littlewood, W. (1999). Defining and developing autonomy in east Asian contexts. Applied Linguistics, 20(1), 71-94. http://dx.doi.org/10.1093/applin/20.1.71

Long, Y. (2012). Analysis of the design concept and function module of foreign languages autonomous learning system-NPELS as an example. Modern Educational Technology, 22(7), 44-48. http://dx.doi.org/10.3969/j.issn.1009-8097.2012.07.009

Luoma, S., \& Tarnanen, M. (2003). Creating a self-rating instrument for second language writing: From idea to implementation. Language Testing, 20(4), 440-465. http://dx.doi.org/10.1191/0265532203lt267oa

Magogwe, J. M., \& Oliver, R. (2007). The relationship between language learning strategies, proficiency, age and self-efficacy beliefs: A study of language learners in Botswana. System, 35(3), 338-352. http://dx.doi.org/10.1016/j.system.2007.01.003

Maurer, T. J., \& Andrews, K. D. (2000). Traditional, Likert, and simplified measures of self-efficacy. Educational and Psychological Measurement, 60(6), 965-973. http://dx.doi.org/10.1177/00131640021970899

Maurer, T. J., \& Pierce, H. R. (1998). A comparison of Likert scale and traditional measures of self-efficacy. Journal of Applied Psychology, 83(2), 324-329. http://dx.doi.org/10.1037/0021-9010.83.2.324

McLoughlin, C., \& Lee, M. J. W. (2010). Personalized and self-regulated learning in the web 2.0 era: International exemplars of innovative pedagogy using social software. Australasian Journal of Educational Technology, 26(1), 28-43. http://dx.doi.org/10.14742/ajet.1100

Miksza, P. (2015). The effect of self-regulation instruction on the performance achievement, musical selfefficacy, and practicing of advanced wind players. Psychology of Music, 43(2), 219-243. http://dx.doi.org/10.1177/0305735613500832

Ministry of Education. (2007). College English curriculum requirements. Beijing: Foreign Language Teaching and Research Press.

Noels, K. A., Pelletier, L. G., Clément, R., \& Vallerand, R. J. (2000). Why are you learning a second language? Motivational orientations and self-determination theory. Language Learning, 50(1), 57-85. http://dx.doi.org/10.1111/0023-8333.00111

Pajares, F. (1996). Self-efficacy beliefs in academic settings. Review of Educational Research, 66(4), 543578. http://dx.doi.org/10.3102/00346543066004543

Schunk, D. H. (1990). Goal-setting and self-efficacy during self-regulated learning. Educational Psychologist, 25(1), 71-86. http://dx.doi.org/10.1207/s15326985ep2501_6 
Schunk, D. H. (1995). Self-efficacy and education and instruction. In J. E. Maddux (Ed.), Self-efficacy, adaptation, and adjustment: Theory, research, and application (pp. 281-303). New York, NY: Plenum Press.

Schunk, D. H. (2003). Self-efficacy for reading and writing: Influence of modeling, goal setting, and selfevaluation. Reading \& Writing Quarterly, 19(2), 159-172. http://dx.doi.org/ 10.1080/10573560308219

Stevens, J. (1996). Applied multivariate statistics for the social science (3rd ed.). Mahwah, NJ: Lawrence Erlbaum.

Tsai, C.-W., Shen, P.-D., \& Fan, Y.-T. (2013). Research trends in self-regulated learning research in online learning environments: A review of studies published in selected journals from 2003 to 2012. British Journal of Educational Technology, 44(5), E107-E110. http://dx.doi.org/10.1111/bjet.12017

Tseng, W. T., Dörnyei, Z., \& Schmitt, N. (2006). A new approach to assessing strategic learning: The case of self-regulation in vocabulary acquisition. Applied Linguistics, 27(1), 78-102. http://dx.doi.org/10.1093/applin/ami046

Tseng, S.-C., Liang, J.-C., \& Tsai, C.-C. (2014). Students’ self-regulated learning, online information evaluative standards and online academic searching strategies. Australasian Journal of Educational Technology, 30(1), 106-121. http://dx.doi.org/10.14742/ajet.242

Ushioda, E. (2003). Motivation as a socially mediated process. In D. Little, J. Ridley, \& E. Ushioda (Eds.), Learner autonomy in the foreign language classroom (pp. 93-129). Dublin: Authentik

Ushioda, E. (2006). Motivation, autonomy and sociocultural theory. In P. Benson (Ed.), Learner autonomy 8: Insider perspectives on autonomy in language learning and teaching (pp. 5-24). Dublin: Authentik.

Wang, C., Kim, D.-H., Bai, R., \& Hu, J. (2014). Psychometric properties of a self-efficacy scale for English language learners in China. System, 44, 24-33. http://dx.doi.org/10.1016/j.system.2014.01.015

Wang, C., Schwab, G., Fenn, P., \& Chang, M. (2013). Self-efficacy and self-regulated learning strategies for English language learners: Comparison between Chinese and German college students. Journal of Educational and Developmental Psychology, 3(1), 173-191. http://dx.doi.org/10.5539/jedp.v3n1p173

Weinstein, C. E., Schulte, A. C., \& Palmer, D. R. (1987). LASSI: Learning and study strategies inventory. Clearwater, FL: H. \& H. Publishing.

Winters, F. I., Greene, J. A., \& Costich, C. M. (2008). Self-regulation of learning within computer-based learning environments: A critical analysis. Educational Psychology Review, 20(4), 429-444. http://dx.doi.org/10.1007/s10648-008-9080-9

Woodrow, L. (2011). College English writing affect: Self-efficacy and anxiety. System, 39(4), 510-522. http://dx.doi.org/10.1016/j.system.2011.10.017

Wu, E., \& Yang, S. C. (2016). Examining the impact of online labeling on tutoring behavior and its effect on the English learning and motivation of low-achieving university students. Computer Assisted Language Learning, 29(2), 316-333. http://dx.doi.org/10.1080/09588221.2014.941370

You, C., \& Dornyei, Z. (2016). Language learning motivation in China: Results of a large-scale stratified survey. Applied Linguistics, 37(4), 495-519. http://dx.doi.org/10.1093/applin/amu046

Yukselturk, E., \& Bulut, S. (2007). Predictors for student success in an online course. Educational Technology \& Society, 10(2), 71-83. Retrieved from http://www.jstor.org/stable/jeductechsoci.10.2.71

Yusuf, M. (2011). Investigating relationship between self-efficacy, achievement motivation, and selfregulated learning strategies of undergraduate students: A study of integrated motivational models. Procedia - Social and Behavioral Sciences, 15, 2614-2617. http://dx.doi.org/10.1016/j.sbspro.2011.04.156

Zheng, C., Liang, J.-C., Yang, Y.-F., \& Tsai, C.-C. (2016). The relationship between Chinese university students' conceptions of language learning and their online self-regulation. System, 57, 66-78. http://dx.doi.org/10.1016/j.system.2016.01.005

Zheng, C., Lu, H., \& Wang, H. (2015). The design and application of an online teaching and formative assessment system for an EFL course in China. Modern Educational Technology, 25(1), 72-78. http://dx.doi.org/10.3969/j.issn.1009-8097.2015.01.011

Zheng, C., Su, Y., \& Lian, J. (2014). Developing an online formative assessment system for a Chinese EFL course. In Y. T. Wu, T. Supnithi, T. Kojiri, C. C. Liu, H. Ogata, S. C, Kong, \& A. Kashihara. (Eds.), Proceedings of the 22nd International Conference on Computers in Education (pp. 532-535). Nara: AsiaPacific Society for Computers in Education. 
Zimmerman, B. J. (2008). Investigating self-regulation and motivation: Historical background, methodological developments, and future prospects. American Educational Research Journal, 45(1), 166183. http://dx.doi.org/10.3102/0002831207312909

Zimmerman, B. J., \& Kitsantas, A. (2014). Comparing students' self-discipline and self-regulation measures and their prediction of academic achievement. Contemporary Educational Psychology, 39(2), 145-155. http://dx.doi.org/10.1016/j.cedpsych.2014.03.004

Zimmerman, B. J., \& Martinez-Pons, M. (1992). Perceptions of efficacy and strategy use in the selfregulation of learning. In D. H. Schunk \& J. Meece (Eds.), Student perceptions in the classroom: Causes and consequences (pp. 185-207). Hillsdale, NJ: Erlbaum.

Zimmerman, B. J., \& Risemberg, R. (1997). Becoming a self-regulated writer: A social cognitive perspective. Contemporary Educational Psychology, 22(1), 73-101. http://dx.doi.org/10.1006/ceps.1997.0919

Zimmerman, B. J., \& Schunk, D. H. (2011). Self-regulated learning and performance: An introduction and overview. In B. J. Zimmerman, \& D. H. Schunk (Eds.), Handbook of self-regulation of learning and performance (pp. 1-15). New York, NY: Routledge Press.

Corresponding author: C. Zheng, zhengchunping@bupt.edu.cn

Australasian Journal of Educational Technology @ 2018.

Please cite as: Su, Y., Zheng, C., Liang, J.-C., \& Tsai, C.-C. (2018). Examining the relationship between English learners' online self-regulation and their self-efficacy. Australasian Journal of Educational Technology, 34(3), 105-121. https://doi.org/10.14742/ajet.3548 


\section{Appendix}

Questionnaire on online self-regulated English learning (Zheng et al., 2016)

\begin{tabular}{|c|c|c|}
\hline Factor & Item & Question \\
\hline \multirow[t]{5}{*}{ Goal setting } & GS1 & $\begin{array}{l}\text { I set short-term (daily or weekly) goals as well as long-term (monthly or for the } \\
\text { semester) goals when learning the English course online. }\end{array}$ \\
\hline & GS 2 & I set standards for my assignments when learning English online. \\
\hline & GS 3 & I keep a high standard for my learning in my online English course. \\
\hline & GS 4 & I set goals to help me manage study time for my online English learning. \\
\hline & GS 5 & $\begin{array}{l}\text { I don't compromise the quality of my work in the English course just because it is } \\
\text { online. }\end{array}$ \\
\hline \multirow{4}{*}{$\begin{array}{l}\text { Environment } \\
\text { structuring }\end{array}$} & ES 1 & I choose a good location for learning English online to avoid too much distraction. \\
\hline & ES 2 & I find an appropriate place for me to concentrate on my online learning of English. \\
\hline & ES 3 & I know where I can learn English online most efficiently. \\
\hline & ES 4 & a time with few distractions when studying English online. \\
\hline \multirow[t]{2}{*}{ Task strategies } & TS 1 & $\begin{array}{l}\text { I try to take more thorough notes for my online courses because notes are even } \\
\text { more important for learning English online than in a regular classroom. }\end{array}$ \\
\hline & TS 2 & $\begin{array}{l}\text { I read aloud the English instructional materials posted online to fight against } \\
\text { distractions. }\end{array}$ \\
\hline Time & TM 1 & I make use of my fragmental time to learn English online. \\
\hline \multirow[t]{2}{*}{ management } & TM 2 & $\begin{array}{l}\text { I try to schedule the same time every day to learn English online, and I observe the } \\
\text { schedule. }\end{array}$ \\
\hline & TM 3 & $\begin{array}{l}\text { Although we don't have to attend daily online English classes, I still try to } \\
\text { distribute my studying time evenly across days. }\end{array}$ \\
\hline \multirow[t]{3}{*}{ Help seeking } & HS 1 & $\begin{array}{l}\text { I find someone who is knowledgeable in online English language learning so that I } \\
\text { can consult with him or her when I need help. }\end{array}$ \\
\hline & HS 2 & $\begin{array}{l}\text { I share my problems with my classmates online so we know what we are } \\
\text { struggling with and how to solve our problems. }\end{array}$ \\
\hline & HS 3 & $\begin{array}{l}\text { If needed, I try to meet my classmates face-to-face and discuss problems when } \\
\text { learning English online. }\end{array}$ \\
\hline \multirow[t]{3}{*}{ Self-evaluation } & SE 1 & $\begin{array}{l}\text { I summarise my online English learning to examine my understanding of what I } \\
\text { have learned. }\end{array}$ \\
\hline & SE 2 & $\begin{array}{l}\text { I ask myself a lot of questions about the course material when studying for an } \\
\text { online course. }\end{array}$ \\
\hline & SE 3 & $\begin{array}{l}\text { I communicate with my teachers to find out how I am doing with my online } \\
\text { English learning. }\end{array}$ \\
\hline
\end{tabular}


Questionnaire on English language self-efficacy (Wang et al., 2014)

\begin{tabular}{|c|c|c|}
\hline Factor & Item & Question \\
\hline \multirow{8}{*}{$\begin{array}{l}\text { Listening } \\
\text { self-efficacy }\end{array}$} & Listening 1 & Can you understand stories told in English? \\
\hline & Listening 2 & $\begin{array}{l}\text { Can you understand radio programs in English speaking countries (like } \\
\text { VOA Special)? }\end{array}$ \\
\hline & Listening 3 & $\begin{array}{l}\text { Can you understand English radio programs made in China (like China } \\
\text { Radio International)? }\end{array}$ \\
\hline & Listening 4 & Can you understand English lectures of general topics? \\
\hline & Listening 5 & Can you understand English songs? \\
\hline & Listening 6 & Can you understand American English TV programs? \\
\hline & Listening 7 & Can you understand English TV programs made in China? \\
\hline & Listening 8 & Can you understand English movies without Chinese subtitles? \\
\hline \multirow{10}{*}{$\begin{array}{l}\text { Speaking } \\
\text { self-efficacy }\end{array}$} & Speaking 1 & Can you describe your university to other people in English? \\
\hline & Speaking 2 & $\begin{array}{l}\text { Can you describe the way to the university sports stadium from the place } \\
\text { where you live in English? }\end{array}$ \\
\hline & Speaking 3 & Can you tell a story in English? \\
\hline & Speaking 4 & Can you ask your English instructor questions in English? \\
\hline & Speaking 5 & Can you answer your English instructor's questions in English? \\
\hline & Speaking 6 & Can you introduce yourself in English? \\
\hline & Speaking 7 & Can you introduce your instructors to someone else in English? \\
\hline & Speaking 8 & $\begin{array}{l}\text { Can you discuss subjects of general interest with your fellow students in } \\
\text { English? }\end{array}$ \\
\hline & Speaking 9 & Can you do English presentations in class? \\
\hline & Speaking 10 & Can you ask people for help in English? \\
\hline \multirow{4}{*}{$\begin{array}{l}\text { Reading } \\
\text { self-efficacy }\end{array}$} & Reading 1 & Can you understand the English news on the Internet? \\
\hline & Reading 2 & Can you read short English narratives? \\
\hline & Reading 3 & Can you read English newspapers? \\
\hline & Reading 4 & Can you understand English articles about Chinese culture? \\
\hline \multirow{6}{*}{$\begin{array}{l}\text { Writing } \\
\text { self-efficacy }\end{array}$} & Writing 1 & Can you write coherent English sentences? \\
\hline & Writing 2 & Can you leave a note for another student in English? \\
\hline & Writing 3 & Can you write email messages in English? \\
\hline & Writing 4 & Can you write English compositions assigned by your English instructor? \\
\hline & Writing 5 & Can you punctuate correctly when you write English essays? \\
\hline & Writing 6 & Can you use accurate grammar when you write English essays? \\
\hline
\end{tabular}

